
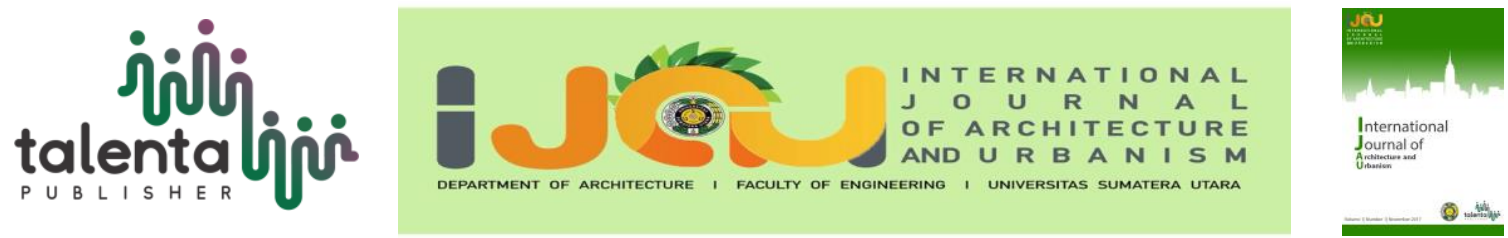

\title{
Performing Art and Culture Center Hamdan
}

\author{
N. Vinky Rahman ${ }^{1 *}$, Esra Monica Aruan ${ }^{1}$ \\ ${ }^{1}$ Architecture Department, Faculty of Engineering, Universitas Sumatera Utara, Medan, Indonesia
}

\begin{abstract}
Performing Art and Culture Center is a building that functions as a center of activity to accommodate the creativity of the community in the field of art as well as public space facilities in the city of Medan. The center for arts and culture is expected to be able to respond to the problem of Medan City in providing community space and informal education facilities so that this function aims as a community space that can accommodate artistic activities with adequate facilities. The method used in designing this project is a data collection through field surveys and literature studies. This project is one of the functions in the revitalization of the Integrated Hamdan Area in Medan Maimun District. To reflect the concept of revival and as an innovative design, the theme of this project is contemporary architecture. This project will be a non-formal education facility that is educational and entertaining. With this function, Performing Arts and Culture can increase tourism in Medan, a place to create value for the creativity of the community, increase the sensitivity of the people of Medan city towards traditional and modern cultural arts, and make Medan a cultured city.
\end{abstract}

Keyword: art, center, culture, revitalization

\section{Introduction}

The urban slum areas that categorized as slums in Indonesia are increasing rapidly every year. Recorded by BPS Medan until 2008, the slum area in Medan reaches $403 \mathrm{Ha}$ in 7 districts consisting of 18 urban villages and continues to increase 1.5\% / year from the total area of the area. Slum areas in Medan City are located on the banks of the Deli River, on the banks of the Babura River, and along the railway rim. Deli River is supposed to be a public area of the city, now used as a private area for slum settlement communities on the riverbanks. The problem causes the Deli River, which was once a vein of trade during the Sultanate Deli is forgotten its history and function as a green area of the city due to polluted by waste and waste.

Departing from this problem, a draft, and revitalization concept is needed in slum areas along the banks of the Deli River. One of the slums that need to revitalize in Medan City is Hamdan Village, located on the edge of Deli River, Hamdan Village, Medan Maimun District.

\footnotetext{
*Corresponding author at: Architecture Department, Faculty of Engineering, Universitas Sumatera Utara, Jalan Perpustakaan Gedung J07, Medan 20155, Indonesia

E-mail address: vinkyrahman@gmail.com
} 
Revitalization of Hamdan Village area into an integrated, self-contained space with several functions in the field of residence, schools, markets, sports centers, and cultural arts centers. One of the revitalization programs is Performing Art and Culture Center Hamdan as a place of cultural art education and community recreation.

\section{Literature Review}

The title of the design is the Performing Art and Culture Center Hamdan. The definition for this design title compiled from several theories from some of the leading figures of art and cultural centers. Performing is to engage in activities that are either demonstrating or presenting a work of music or other performances in front of the audience [1]. Art is a skill gained from learning experience or observation[2]. Culture is all the intellectual and artistic statements that characterize a society[3]. Center, according to the Oxford dictionary is a place or group of buildings where certain activities are centered [1]. Hamdan is the name of the design site in the Hamdan Integrated Territory, Hamdan Village, Medan Maimun Sub-district, Medan. So, it can be concluded that "Performing Art and Culture Center Hamdan" is a building or group of buildings that is the center of activity to accommodate useful, innovative, and varied creativity in the field of art and pour the art in the form of performance art in order to serve the public and meet the need for artistic interest. This arts center is presented with the hope that it can be a means of learning, preserving, appreciation all matters relating to art and culture and as a space facility in the city of Medan, consisting of galleries, libraries and theatre is an art complex that fosters the artistic spirit of the people of Medan City.

The Performing Art and Culture Center Hamdan uses Contemporary Architecture. Contemporary can interpret as a more advanced, varied, flexible, and innovative design, both in form and appearance, material type, material processing, asymmetric shape and technology used will be the trend in the last years[4]. Characteristics of Contemporary Architecture: (1) The design displays a newer style; (2) Highlighting the unique, out of the ordinary, attractive, and very complex; (3) The plan is a row-shaped curve that randomly scrambled; (4) Typical textured materials, such as wood, marble, etc.

Contemporary architecture is a work of architecture that is always changing or up to date, design changes that always try to adjust with time. The design changes in shape, appearance, material type, processing, and technology used.

\section{Comparative Study of Similar Functions}

Komunitas Salihara has been the first private art center in Indonesia since August 08, 2008, located on a plot of land of about 3,800 $\mathrm{m}^{2}$ at Salihara 16 Road, Pasar Minggu, Jakarta which is surrounded by residential area connected to 2 main roads namely Pejaten Raya Road and Ragunan Raya Road (Figure 1). 


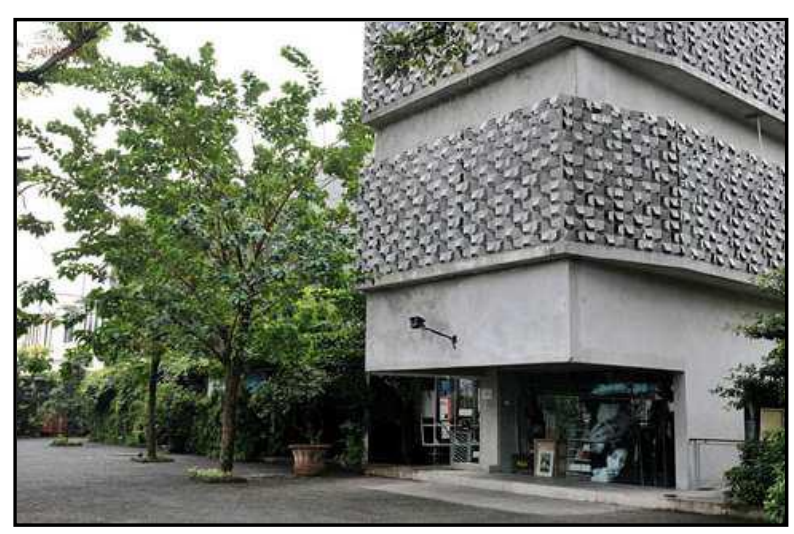

Figure 1. Komunitas Salihara, Jakarta

Komunitas Salihara consists of three central building units: Salihara Theater, Salihara Gallery, and office space. Komunitas Salihara visited who want to enjoy art and thought programs, classic and cutting-edge, and high quality. Also, Komunitas Salihara became a gathering place for various interest groups such as writers, filmmakers, choreographers, young architects, philosophers, translators, book lovers, and others. Komunitas Salihara can also call an alternative cultural center because it not owned by the central government or foreign embassies. The vision of Komunitas Salihara is to maintain freedom of thought and expression, respect for diversity and diversity, and to grow and spread artistic and intellectual wealth [5].

\section{Methodology}

The selection of space and program criteria for the Performing Art and Culture Center Hamdan design based on the grouping of several sites. That has tested the feasibility of achieving the viability of facilities around the site, the shortest distance to the activity center in Medan City by a direct survey to the location to obtain the data of the area. Then in determining the program space and good standards obtained from several comparative studies by approaching problems and cases that have similarities in the design of similar or theme in the title of this design taken from various sources such as books, the Internet, print and other media and sources which is considered important.

\section{Result and Discussion}

Performing Art and Culture Center Hamdan, located in Hamdan Village, situated on the edge of Deli River, Hamdan Village, Medan Maimun, Medan City, North Sumatera (Figure 2). 


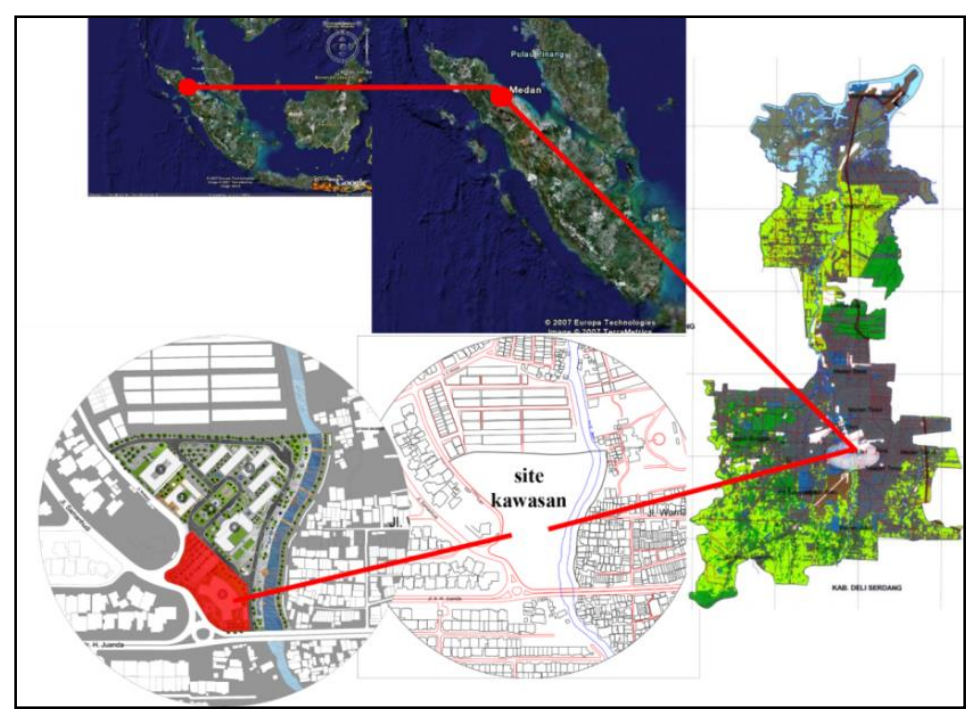

Figure 2. Location of design

Performing Art and Culture Center Hamdan is located at the intersection of Samanhudi Road and IR Juanda Road, Hamdan Sub-district, Medan Maimun Sub-district, Medan, North Sumatera with an area of \pm 1.0 Ha. Performing Art and Culture Center, which is one of the functions in the Hamdan Integrated Area, borders the sports center building on the north, Plaza, and the Deli River in the east, IR Juanda Road in the south, and Samanhudi Road in the west (Figure 3).

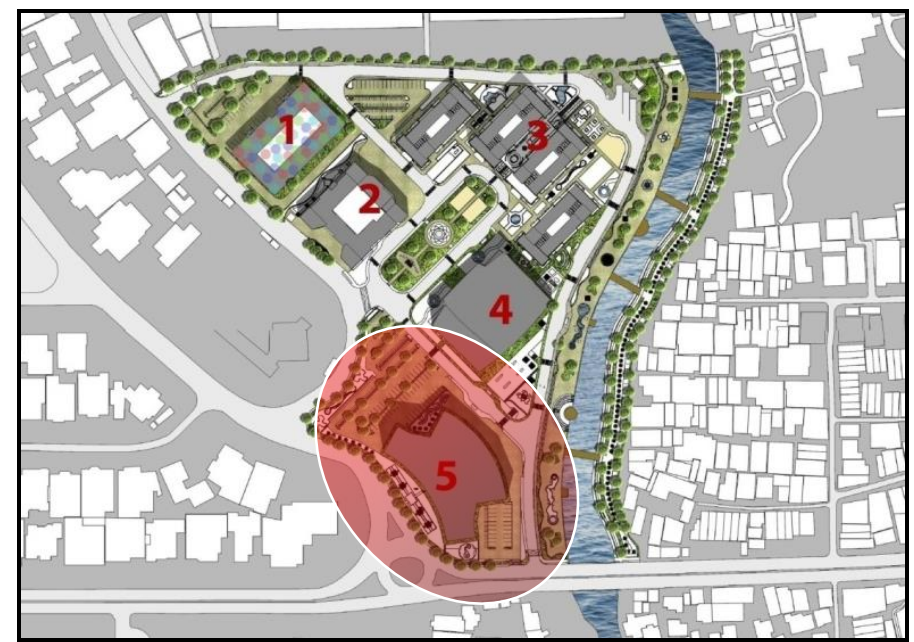

Figure 3. Location of Performing Art and Culture Center Hamdan

\section{The Building Concept}

The mass formation of Performing Art and Culture Center Hamdan is building inspired by the creation of a square, which later on the building was given a curved out the form on the back that would be used as a theatre function and as a response to the river view. Then at the front is given a curve to go inside to respond to the formation of an arch at the site and perspective to the area through IR Juanda Road to provide additional views of the building. (Figure 4) 


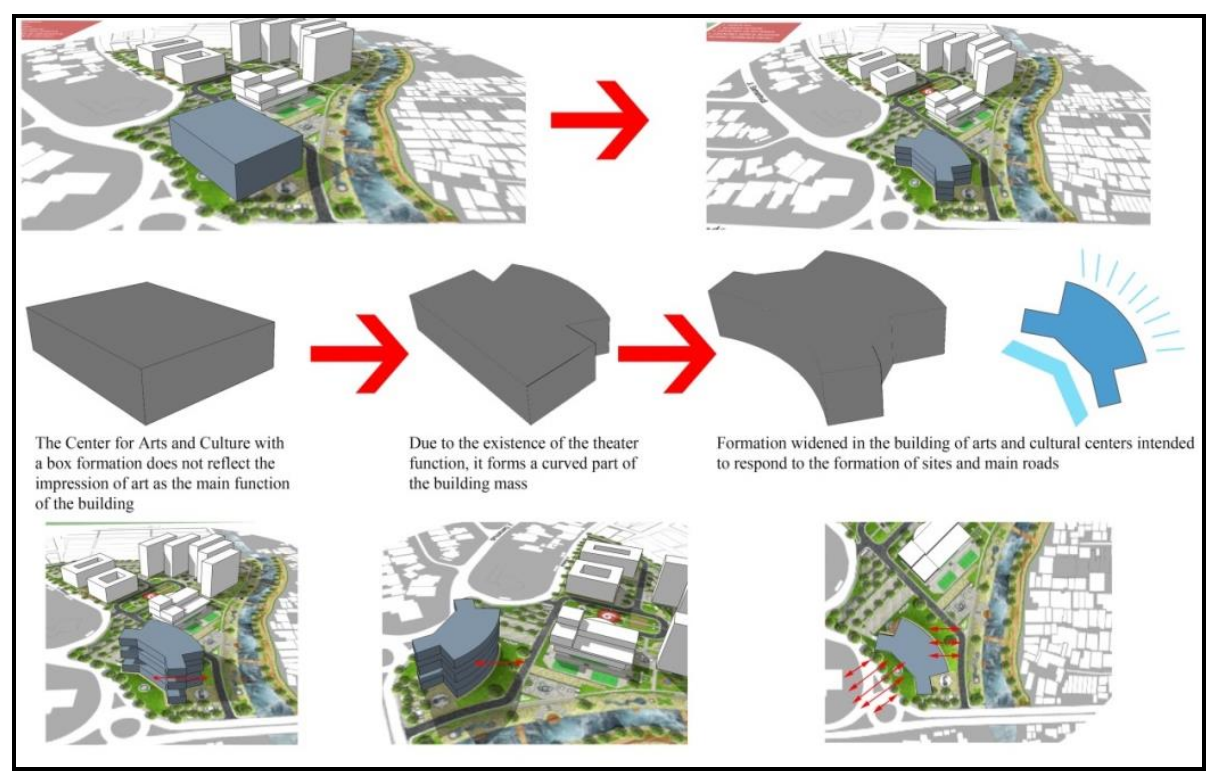

Figure 4. The concept of Performing Art and Culture Center Hamdan

\section{The Landscape Concept}

This design has a circulation landscape concept on every corner of the site that can be reached by pedestrians. The idea of landscaping to the facility that is the place of recreation on the site adds the value of the impression of space, coupled with a different atmosphere at each corner then the aesthetic value of the site will increase. The site will be placed in a parking area that will only be used by the visitors' building due to the number of visitors with high intensity, making it easier to achieve the structure. (Figure 5)

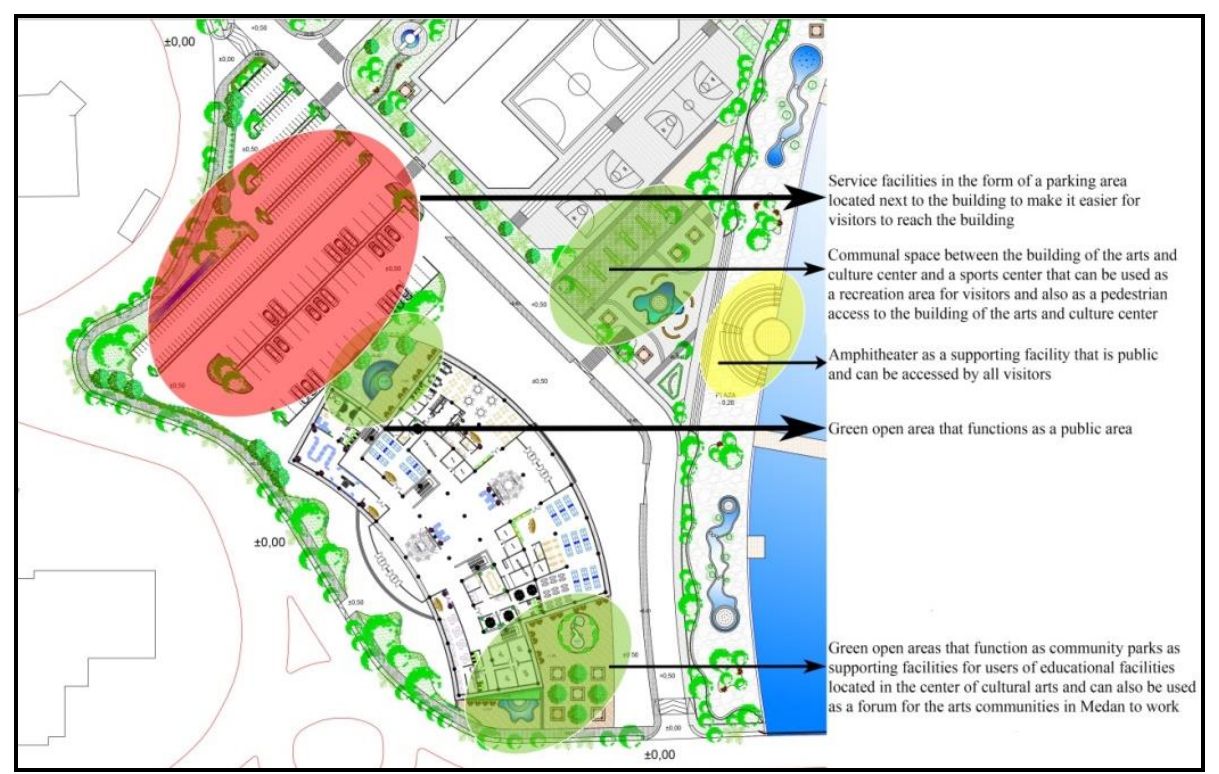

Figure 5. The landscape concept of Performing Art and Culture Center Hamdan

\section{Path of Site's Circulation}

Pedestrian access within the Hamdan Integrated Territory is planned to access all corners of the site. It is intended to facilitate the achievement of every function, including the cultural arts 
center. Vehicle access within the Hamdan Integrated Territory is planned to surround every function. It is intended to facilitate the achievement of tasks by the vehicle. The Hamdan Integrated Territory has a bus as transport within the area, making it easier to access every function within the district.

Vehicle circulation can reach through IR Juanda Road and Multatuli Road. With the two main paths leading to the building of the Center of Art and Culture facilitate visitors in achieving the function of the structure, and to avoid the occurrence of congestion within the area. As for the circulation path out of the building also to IR Juanda Road and Samanhudi Road is the main road around the Hamdan area. The pedestrian circulation of the Hamdan region's quarry that can reach the Arts and Culture Center building is at the intersection of Samanhudi Road and IR Juanda Road. With the presence of pedestrian lanes, the achievement of buildings for users using public transportation is more accessible to reach. (Figure 6)

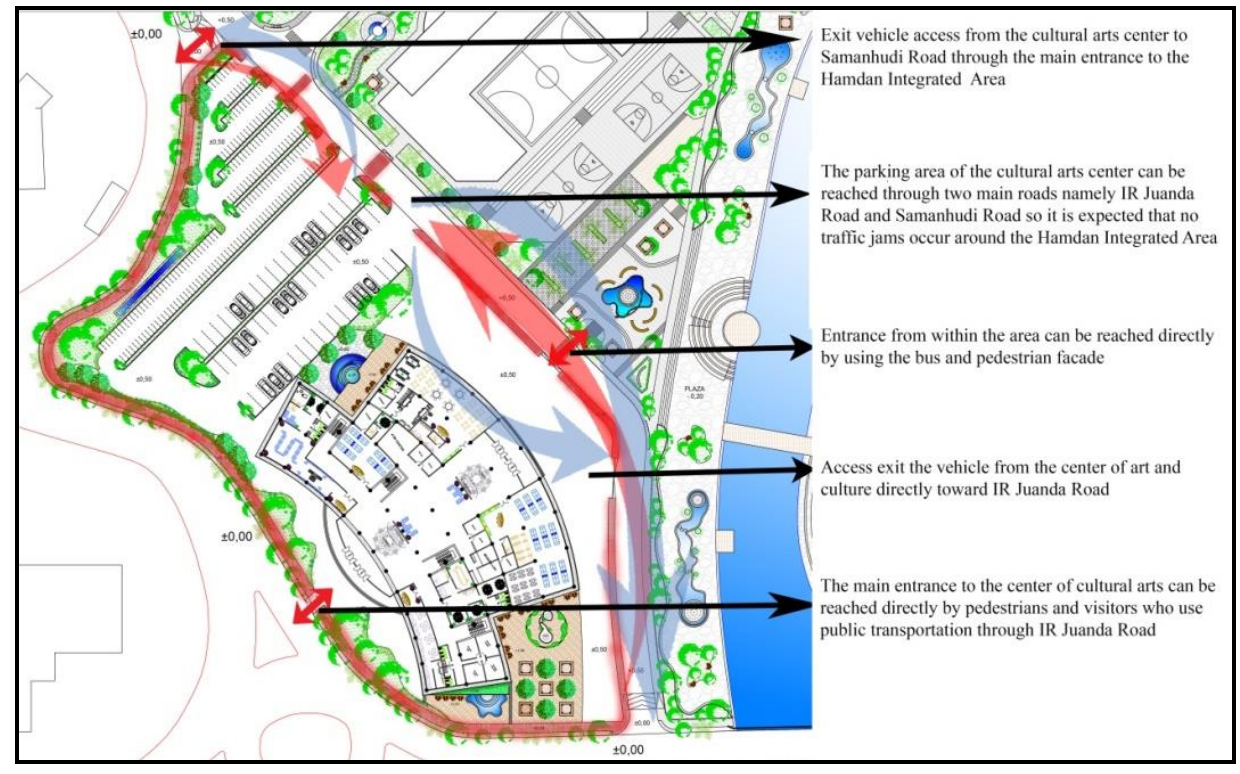

Figure 6. Circulation site

\section{The Concept of Floor Plan}

Performing Art and Culture Center Hamdan divided into major facilities, public facilities, support facilities, vertical circulation, and service areas. Public facilities, supporting facilities and service facilities located on the ground floor such as a library, restaurant, cafe, art gallery center, art store, and the management office placed on the ground floor. It is intended so that its activities do not disturb the space that is private. Areas of major facilities such as auditoriums, educational facilities, and multipurpose rooms are on the second floor. The vertical circulation area and service area located at the ends of the building. It is intended to facilitate the achievement of the circulation path in the structure. (Figure 7) 


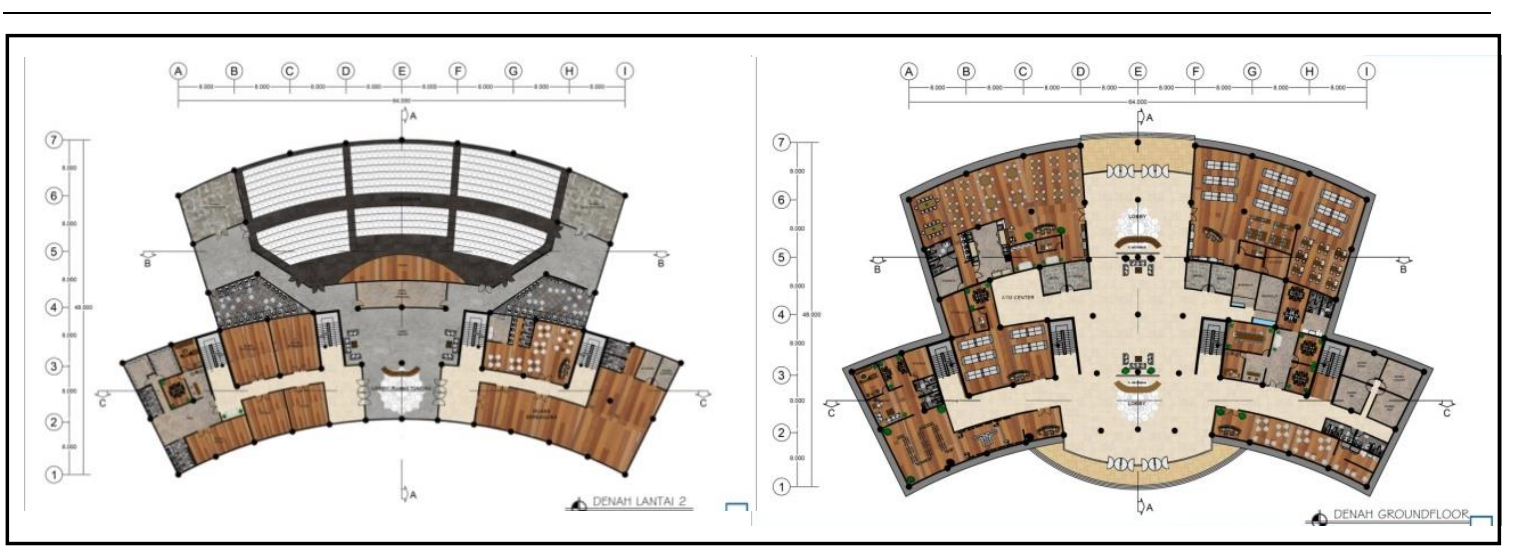

Figure 7. Design floor plan

\section{The Concept of Structure Building System}

The concept used as a structure in this building as a long span structure used in building performance with columns up to 8 meters. Because the building only has two floors, the foundation used is the foot plate foundation. On the roof of the building was the dome-shaped form. (Figure 8)

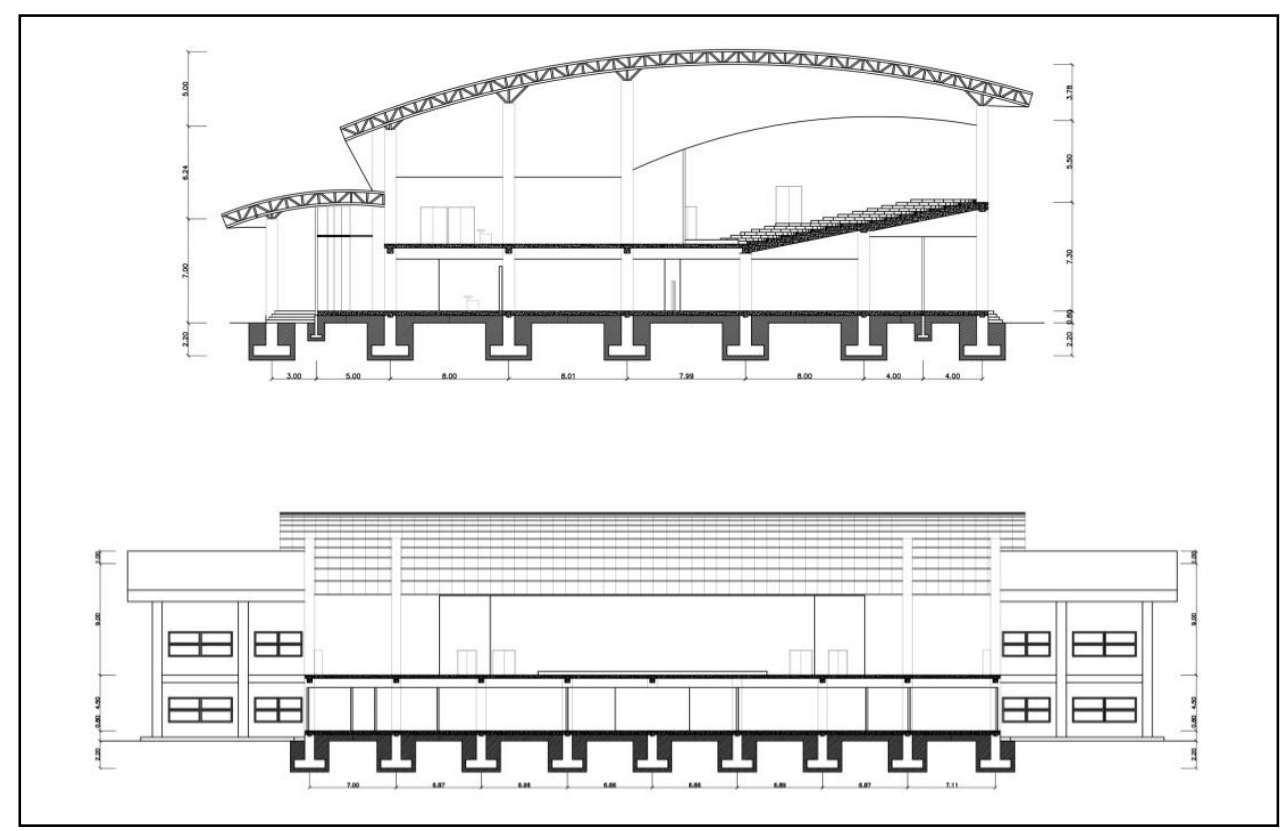

Figure 8. Structure building section

The upper structure uses a regular concrete column with a span of columns in a column of 8 meters, but in the performance, the section using a spanning structure dome-shaped truss space to withstand tensile loads and press because there are only columns on the perimeter of the performance building.

\section{The Final Design}

The final design of the cultural arts center applies the modern concept of utilizing the roof formation as the architectural value of the building. The building is designed to accommodate 
the existing arts activities in the city of Medan and as a means of educational - recreational for young people of Medan. (Figure 9 and 10)

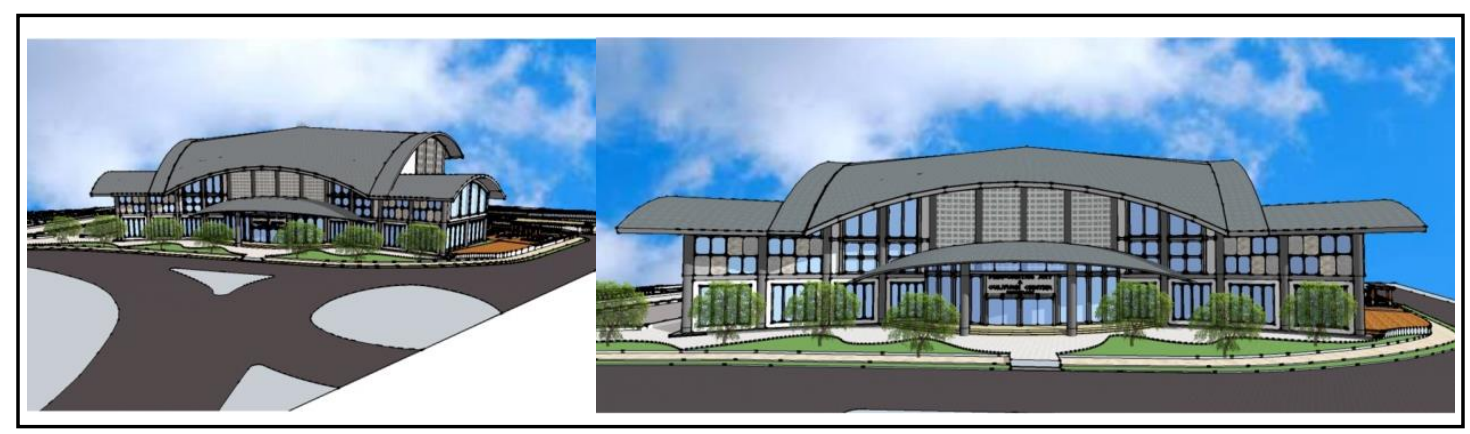

Figure 9. Perspective exterior

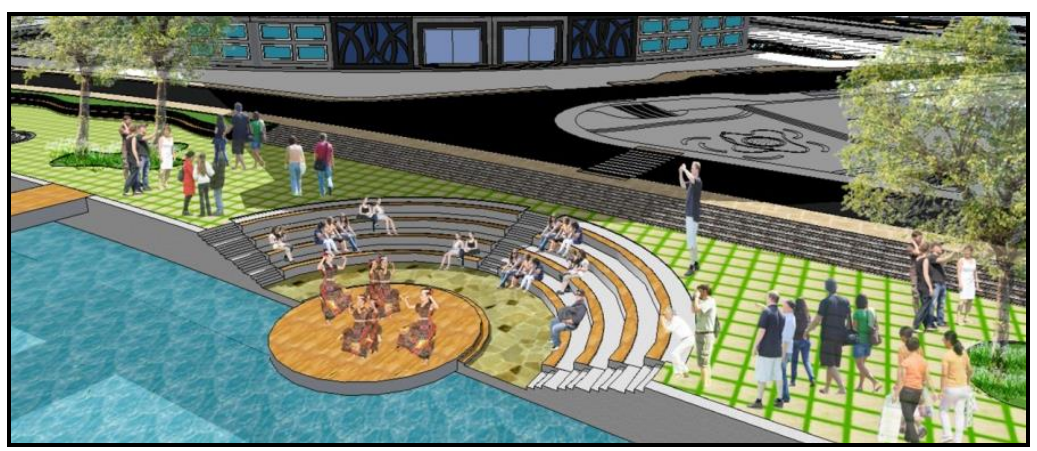

Figure 10. Perspective of amphitheater

\section{Conclusion}

Performing Art and Culture Center Hamdan is a center for the development and fostering of art that is educational and recreational that can meet the artistic needs of the people of Medan City and as a means of creative young generation and the artists of Medan City. This building accommodates art activities through both education and performing arts and can serve as a forum for the gathering of artistic communities. It expected that the Performing Art and Culture Center Hamdan could improve the quality of the non-formal education of the people of Medan City and improve the appreciation and creativity of the people of Medan City in particular and the people of Indonesia in general.

Performing Art and Culture Center Hamdan is a building or group of buildings that is the center of activity to accommodate useful, innovative, and varied creativity in the arts and pure art in the form of performing arts to serve the wider community and meet the needs of interest the artists. This cultural arts center is presented with the hope to be a means of learning, preservation, all matters relating to art and culture and as a space facility in the city of Medan, consisting of galleries, libraries and theatre are an art complex that fosters the spirit of community art Medan. 


\section{Acknowledgment}

This article was prepared by researchers as a part of funding by Universitas Sumatera Utara to the City Government to dedicate expertise in the field of architecture based on local wisdom planning and design.

\section{REFERENCES}

[1] A. S. Hornby, S. Wehmeier, and M. Ashby, Oxford advanced learner's dictionary. 2000.

[2] Kamus Besar Bahasa Indonesia (KBBI), 2007. [Online]. Available: https://kbbi.kemdikbud.go.id/.

[3] A. Eppink, "Ilmu Budaya Dasar," Edisi Revisi IV.

[4] M. Suparmoko, Gagasan bentuk dan arsitektur: prinsip-prinsip perancangan dalam arsitektur kontemporer, Bandung: Intermatra. 1988.

[5] Komunitas Salihara. [Online]. Available: http://www.salihara.org/. 